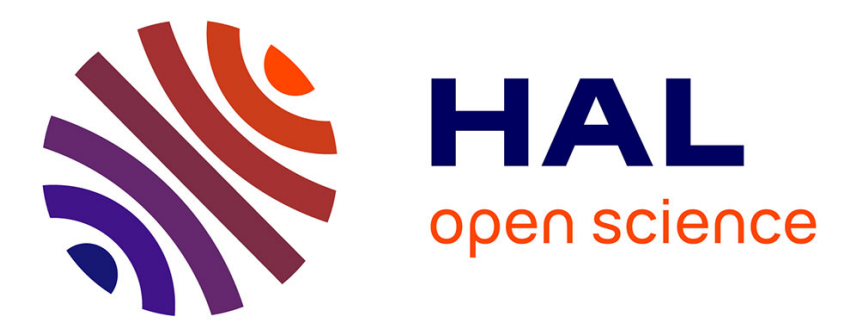

\title{
Holocene dust dynamics: Introduction to the special issue
}

\author{
François de Vleeschouwer, Jan-Berend Stuut, Fabrice Lambert
}

\section{To cite this version:}

François de Vleeschouwer, Jan-Berend Stuut, Fabrice Lambert. Holocene dust dynamics: Introduction to the special issue. The Holocene, 2020, 30 (4), pp.489-491. 10.1177/0959683619892670 . hal02895449

\section{HAL Id: hal-02895449 \\ https://hal.science/hal-02895449}

Submitted on 10 Nov 2020

HAL is a multi-disciplinary open access archive for the deposit and dissemination of scientific research documents, whether they are published or not. The documents may come from teaching and research institutions in France or abroad, or from public or private research centers.
L'archive ouverte pluridisciplinaire HAL, est destinée au dépôt et à la diffusion de documents scientifiques de niveau recherche, publiés ou non, émanant des établissements d'enseignement et de recherche français ou étrangers, des laboratoires publics ou privés. 


\title{
Holocene dust dynamics: Introduction to the Special Issue
}

\author{
François De Vleeschouwer ${ }^{1}$, Jan-Berend W. Struut ${ }^{2}$ and Fabrice Lambert ${ }^{3}$
}

${ }^{1}$ François De Vleeschouwer Instituto Franco-Argentino para el Estudio del Clima y sus Impactos (UMI IFAECI/CNRS-CONICETUBA-IRD), Dpto. de Ciencias de la Atmosfera y los Oceanos, FCEN, Universidad de Buenos Aires, Intendente Guiraldes 2160 - Ciudad Universitaria, Pabellon II - 2do. Piso, (C1428EGA) Ciudad Autonoma de Buenos Aires - Argentina Phone : +54 11 5285-8458 Email: fdevleeschouwer@cima.fcen.uba.ar www.cima.fcen.uba.ar

2 Jan-Berend W. Stuut NIOZ - Royal Netherlands Institute for Sea Research, and Utrecht University Landsdiep 4, 1797 SZ Den Hoorn, Texel, The Netherlands Phone : +31 222369405 Email : jbstuut@nioz.nl www.nioz.nl/dust

${ }^{3}$ Fabrice Lambert Millennium Nucleus Paleoclimate, Center for Climate and Resilience Research Department of Physical Geography, Pontifical Catholic University of Chile Ph: +56 223544728 Email : lambert@uc.cl

\begin{abstract}
This article is a brief introduction to the Special Issue on Holocene Dust Dynamics, which brings together recent research on a key aspect of the Earth's changing climate through its effects on radiative balance, cloud cover and biogeochemical cycles. The aim of the Special Issue is to contribute to a better understanding of the role of dust aerosols by analysing the evolution and climatic impact of atmospheric dust over long and short timescales within the Holocene. Here we introduce the rationale behind the Special Issue and the eight research papers, which include long term records of dust deposition from different types of natural archive (e.g. peatlands, ice, loess and lake sediments) as well as present-day multi-annual dust trap records and process studies from various climatic regimes that have global implications.
\end{abstract}

\section{Keywords}

Atmospheric dust, climate change, aerosols, natural archives, Holocene

\begin{abstract}
Main text
Atmospheric dust is a key player in Earth's climate. It affects the planet's radiative balance directly by reflecting incoming shortwave solar radiation and absorbing outgoing longwave radiation (e.g. Miller et al., 2014). It also influences the climate indirectly by acting as condensation nuclei for clouds (e.g. Lohmann and Feichter, 2005) and by affecting biogeochemical cycles through micronutrient supply to the terrestrial and marine biospheres (Boy and Wilcke, 2008; Mahowald, 2011; Yu et al., 2015). Unlike greenhouse gases, whose effect on climate is relatively well constrained, the uncertainty of aerosols, and mineral dust in particular, on climate change is comparatively large (Huneeus et al., 2011; Myhre et al., 2013). This is true for both current as well as past large-scale climatic changes.
\end{abstract}

The processes of emission, transport, and deposition of atmospheric dust and its climatic impacts vary with past and current climate and environmental changes. Atmospheric dust is intimately linked to global paleoclimatic change, with exponentially higher and lower atmospheric dust loads during colder and warmer periods, respectively (e.g. Maher et al., 2010; Lambert et al., 2013). Increased or reduced dust concentrations also feed back on the climate system through dust's direct and indirect effects. Shaffer and Lambert (2018) recently showed that dust loads during glacial maxima may be responsible for a global cooling of $1^{\circ} \mathrm{C}$ due to combined dust-climate feedbacks. The latest IPCC reports also suggest a global negative radiative forcing of atmospheric dust on global climate but also point out to a relative uncertainty in the calculation of that budget (IPCC 2014). Conversely, Ellis and Palmer (2016) argue that dust deposition during glacial times may have triggered accelerated melting of ice globally through decreasing the earth's albedo. 
Atmospheric dust deposition/flux is also an indicator for aridity and wind system changes. Higher precipitation will wash out more dust from the atmosphere (Yung et al., 1996), while stronger winds will entrain more and coarser-grained particles from the surface (McGee et al., 2010 QSR; Van der Does et al., 2016). Therefore, dust deposition records can be used to reconstruct past wind and atmospheric dynamics as well as the activity of dust sources (i.e. deserts) (e.g. De Vleeschouwer et al., 2014; Albani et al., 2015). High uncertainties in reconstructing past dust fluxes however limit our knowledge of the relative contributions of dust source changes, wind changes, and hydrological cycle changes during past times which translates into highly variable estimates of dust deposition. Moreover, in modern times, dust emissions have at least doubled over the past two centuries due to anthropogenic influence (Mahowald et al., 2010; Mulitza et al. 2010; IPCC 2014; Hooper and Marx, 2018), with consequences that are still uncertain (Kok et al., 2018)

To summarize, climate and dust have mutual interactions and one will alter the other in many ways, resulting in a feedback paradigm: global climate is affected by atmospheric dust variations and the generation, transport and deposition of atmospheric dust is itself modulated by climate. Studying past and present atmospheric dust behaviour and understanding those climate-dust feedbacks may therefore help forecasting future climate-dust interactions. The broad aim of this special issue is to contribute to the general goal of a better understanding of dust aerosols by analysing in detail the evolution and climatic impact of atmospheric dust during to the Holocene. It follows the DICE working group initiative and guidelines (http://www.pages-igbp.org/workinggroups/global-monsoon/143working-group/dice/861-dice) in compiling a series of past and present-day atmospheric dust records from various areas. The first part of the special issue is dedicated to the most prominent archives of atmospheric dust that are used nowadays: peatlands, ice and loess. Those first papers show how it is possible to reconstruct dust deposition fluxes and sources and decipher climatic information such as wind regimes, positions and intensities in various climatic conditions from seasonal to monsoonal regimes (Pratte et al. this issue, Martinez-Cortizas et al. this issue, Hooper et al. this issue). While peatlands provide detailed and high-resolution chronologies, they are generally limited to the Holocene or the last glacial termination, while loess and ice provide a longer prospective. The two papers presented in this issue are a perfect example of the source to sink transport of dust. Loess from South American Pampas do not only provide a reconstruction of past climatic conditions over several MIS (Torre et al., this issue), but also provide source characterizations to dust deposited in Antarctica (Delmonte et al. this issue). When those archives are not available in a given geographical area, lake sediments can provide an alternative, given specific conditions, to disentangle the atmospheric signal from the watershed erosion (Arcusa et al., this issue). These contributions about past atmospheric dust are closely dependant on present day dust studies as while "the past is the key to understand our future", present day studies help validate hypothesis made from past dust archives. They also greatly help understanding the processes behind the dust cycle in terms of climatic feedbacks, transport and effects on living organisms and ecosystems. The last two contributions of this special issue perfectly illustrate those aspects. Cosentino et al. (this issue) present a very detailed study of the dust deposition in Southern South America over the last 14 years and greatly help understanding how dust is generated, transported and deposited over a continent, while Bigelow et al. (this issue) contribute to our understanding of the importance of atmospheric dust as fertilizer in environments where nutrients are limited as well as on the availability and degradability of dust components that may play an important role on metabolic functions of bacteria, at the base of the trophic chain of some ecosystems.

\section{Acknowledgements}

Guest editors FDV, JBS and FL warmly thank editor J. Matthews and Holocene submission website manager Oliver for their help during the review and built up of this special issue. The PAGES DICE working group as well as the Climat AmSud project provided financial support to guest editors and selected participants to attend workshops and prepare this special issue

\section{References}

Albani, S. Mahowald N. M., Winckler G., Anderson R. F., Bradtmiller L.I., Delmonte B., François R., Goman M., Heavens N. G., Hesse P. P., Hovan S. A., Kang S. G., Kohfeld K.E., Lu H., Maggi V., Mason J. A., Mayewski P. A., McGee D., Miao X., Otto-Bliesner B.L., Perry A.T., Pourmand A., Roberts H. M., Rosenbloom N., Stevens T. and Sun J. (2015). Twelve thousand years of dust : the Holocene 
global dust cycle constrained by natural archives, Clim. Past, 11(6), 869--903, doi:10.5194/cp-11-8692015.

Arcusa S., McKay N.P., Routson C.C. and Munoz S.E. (this volume). Dust-drought interactions over the last 15,000 years: a network of lake sediment records from the Jan Juan Mountains, Colorado, USA

Bigelow A., Mladenov N., Lipson D. and Williams M. (this volume). Dust deposition drives microbial metabolism in a remote high-elevation catchment

Boy, J., and W. Wilcke (2008). Tropical Andean forest derives calcium and magnesium from Saharan dust. Global Biogeochem. Cycles, 22(1), 1-11, doi:10.1029/2007GB002960.

Cosentino N.J., Gaiero D.M., Torre G., Pasquini A.I., Coppo R., Arce J.M. and Vélez G. (this volume). Atmospheric dust dynamics in southern South America: a 14-year modern dust record in the loessic Pampean region.

Delmonte B., Winton H., Baroni M., Baccolo G., Hansson M., Andersson P., Baroni C., Salbatore M.C., Lanci L. and Maggi V. (this volume). Holocene dust in East Antarctica: provenance and variability in time and space

De Vleeschouwer F., Ferrat M., McGowan H., Vanneste H. and Weiss D. (2014). Extracting paleodust information from peat geochemistry. PAGES Magazine: Past Global Changes Magazine 22 (2), 88-89

Ellis R. and Palmer M. (2016). Modulation of ice ages via precession and dust-albedo feedbacks. Geoscience Frontiers 7, 891-909.

Hooper J., Marx S.K., May J.-H, Lupo L.C., Kulemeyer J.J., Seki O., Heijnis H. and Child D. (this volume). Dust deposition tracks late Holocene shifts in monsoon activity and the increasing role of human disturbance in the Puna-Altiplano, northwest Argentina

Hooper J. and Marx S. (2018). A global doubling of dust emissions during the Anthropocene?, Glob. Planet. Change, 169, 70-91, doi:10.1016/j.gloplacha.2018.07.003.

Huneeus N. Schulz M., Balkanski Y., Griesfeller J., Prospero J., Kinne S., Bauer S., Boucher O., Chin M., Dentener F., Diehl T., Easter R., Fillmore D., Ghan S., Ginoux P., Grini A., Horowitz, L., Koch D., Krol M. C., Landing W., Liu X., Mahowald N., Miller R., Morcrette J.-J., Myhre G., Penner J., Perlwitz J., Stier P., Takemura T. and Zender C. S. (2011).Global dust model intercomparison in AeroCom phase I, Atmos. Chem. Phys., 11(15), 7781-7816, doi:10.5194/acp-11-7781-2011.

IPCC (2014). Climate Change 2014: Synthesis Report. Contribution of Working Groups I, II and III to the Fifth Assessment Report of the Intergovernmental Panel on Climate Change [Core Writing Team, R.K. Pachauri and L.A. Meyer (eds.)]. IPCC, Geneva, Switzerland, 151 pp.

Kok J.F., Ward D.S., Mahowald N.M. and Evan A.T. (2018). Global and regional importance of the direct dust-climate feedback. Nature Communications, https://doi.org/10.1038/s41467-017-02620-y

Lambert F., Kug J.-S. Park R. J. Mahowald N. Winckler G, Abe-Ouchi, A. O'ishi R., Takemura T. and Lee J.-H. (2013). The role of mineral-dust aerosols in polar temperature amplification, Nature Climate Change, 3(5), 487-491, doi:10.1038/nclimate1785.

Lohmann U. and Feichter J. (2005). Global indirect aerosol effects: a review, Atmos. Chem. Phys., 5(3), 715-737, doi:10.5194/acp-5-715-2005.

Maher B., Prospero J. M., Mackie D., Gaiero D., Hesse P. P. and Balkanski Y. (2010). Global connections between aeolian dust, climate and ocean biogeochemistry at the present day and at the last glacial maximum, Earth-Science Rev., 99(1-2), 61-97, doi:10.1016/j.earscirev.2009.12.001.

Mahowald N. M., Kloster S., Engelstaedter S., Moore J. K., Mukhopadhyay S., McConnell J. R., Albani S., Doney S. C., Bhattacharya A., Curran M. A. J., Flanner M. G., Hoffman F. M., Lawrence D. M., 
Lindsay K., Mayewski P. A., Neff J., Rothenberg D., Thomas E., Thornton P. E., and Zender C. S. (2010). Observed 20th century desert dust variability: impact on climate and biogeochemistry, Atmos. Chem. Phys., 10(22), 10875-10893, doi:10.5194/acp-10-10875-2010.

Mahowald N. M. (2011). Aerosol Indirect Effect on Biogeochemical Cycles and Climate, Science 334(6057), 794-796, doi:10.1126/science.1207374.

Martínez Cortizas A., López-Costas O., Orme L., Mighall T. Kylander M.E., Bindler R. and Gallego Sala A. (this volume). Holocene atmospheric dust deposition in NW Spain

McGee D., Broecker W.S. and Winkler G. (2010). Gustiness: The driver of glacial dustiness? Quaternary Science reviews $29: 2340-2350$.

Miller R. L., Knippertz P., Pérez García-Pando C., Perlwitz J. P., and Tegen I. (2014). Impact of Dust Radiative Forcing upon Climate, in Mineral Dust, edited by P. Knippertz and J.-B. W. Stuut, pp. 327357, Springer Netherlands, Dordrecht.

Mulitza S., Heslop D., Pittauerova D., Fischer H.W., Meyer I., Stuut J.-B., Zabel M., Mollenhauer G., Collins J.A., Kuhnert H. and Schulz M. (2010). Increase in African dust flux at the onset of commercial agriculture in the Sahel region. Nature 466, 226-228.

Myhre G., Shindell D., Bréon F.-M., Collins W., Fuglestvedt J., Huang J., Koch D., Lamarque J.-F., Lee D., Mendoza B., Nakajima T., Robock A., Stephens G., Takemura T. and Zhang H. (2013). Anthropogenic and Natural Radiative Forc-ing. In: Climate Change 2013: The Physical Science Basis. Contribution of Working Group I to the Fifth Assessment Report of the Intergovernmental Panel on Climate Change [Stocker, T.F., D. Qin, G.-K. Plattner, M. Tignor, S.K. Allen, J. Boschung, A. Nauels, Y. Xia, V. Bex and P.M. Midgley (eds.)]. Cambridge University Press, Cambridge, United Kingdom and New York, NY, USA.

Pratte S., Bao K., Sapkota A., Zhang W., Shen J., Le Roux G. and De Vleeschouwer F. (this volume). 14-kyr of atmospheric mineral dust deposition in north-eastern China: an interplay between the Westerlies and the East Asian monsoon?

Shaffer G., and Lambert F. (2018). In and out of glacial extremes by way of dust-climate feedbacks. Proc. Natl. Acad. Sci., 201708174, doi:10.1073/pnas.1708174115.

Torre G., Gaiero D.M., Cosentino N.J., Coppo R. and Sawakucji A.O. (this volume). New insights on sources contributing dust to the loess record of the western edge of the Pampean Plain during the transition from the late MIS 2 to the early Holocene

van der Does M., Korte L.F., Munday C.I., Brummer G.J.A. and Stuut J.B.W. (2016). Particle size traces modern Saharan dust transport and deposition across the equatorial North Atlantic. Atmos. Chem. Phys. 16, 13697-13710.

Yu H., Chin M., Yuan T., Bian H., Remer L.A., Prospero J.M., Omar A., Winker D., Yang Y., Zhang, Y., Zhang Z. and Zhao C. (2015). The Fertilizing Role of African Dust in the Amazon Rainforest: A First Multiyear Assessment Based on CALIPSO Lidar Observations. Geophysical Research Letters, n/an/a.

Yung Y.K., LeeT. Wang C.-H. and Shieh Y.-T. (1996). Dust: A Diagnostic of the Hydrologic Cycle During the Last Glacial Maximum. Science Vol. 271, Issue 5251, pp. 962-963 DOI: $10.1126 /$ science.271.5251.962 